\title{
Housing standards and excess winter mortality
}

\author{
J Peter Clinch, John D Healy
}

The winter peak in mortality has been shown to be related to cold stress in a number of countries. ${ }^{1}$ There are $30000-60000$ excess winter deaths in the United Kingdom annually. In Ireland, the equivalent figure is $1500-2000$ deaths. This winter surplus accounts for a rate of seasonal variation in mortality of $15 \%$, among the highest in Europe. ${ }^{2}$ Paradoxically, Ireland has a relatively mild winter (mean temperature of $5^{\circ} \mathrm{C}$ ) whereas countries with more severe winter conditions exhibit significantly lower variations in seasonal mortality (for example, Denmark and Norway have mean winter temperatures below freezing but 5\% seasonal mortality variation). ${ }^{2}$ This paper hypothesises a link between poor housing standards (in terms of thermal efficiency and heating systems) and high rates of excess winter mortality in Ireland.

\section{Methods \\ Norway was chosen for comparison with Ireland. A comparative analysis of risk factors for cardiovascular ${ }^{3}$ and respiratory diseases ${ }^{4}$ and of housing standards was undertaken. Registered monthly mortality data from 1986- 1995 were obtained from the Irish Central Statistics Office and Statistics Norway. Data on mortality from cardiovascular disease (ICD- code 390-459), respiratory disease excluding influenza (ICD-code 460-486; 490-519) and "all causes" (ICD-code 000-999) were exam- ined. Proportionate and crude mortality rates per 1000 population for cardiovascular and respiratory disease were calculated. Excess winter mortality was calculated by comparing the number of deaths per day during the winter period, December to March, with that of the non-winter period, April to November, for each year. Relative excess winter mortality was calculated by dividing daily excess winter deaths by daily non-winter deaths. ${ }^{5}$}

Results

Minimum residential insulation standards in Ireland and Norway differ substantially. Using averages for 1986-1995, roof insulation was $100 \mathrm{~mm}$ in Ireland and $200 \mathrm{~mm}$ in Norway; wall insulation was $40 \mathrm{~mm}$ and $125 \mathrm{~mm}$ in Ireland and Norway respectively; floor insulation was $150 \mathrm{~mm}$ in Norway and $25 \mathrm{~mm}$ in Ireland. Average internal temperatures of $15^{\circ} \mathrm{C}$ and $21^{\circ} \mathrm{C}$ are reported for Irish and Norwegian homes respectively.

Winter environmental temperatures are colder in Norway than Ireland (mean (19861995) January temperatures of $-1.1^{\circ} \mathrm{C}$ and $5^{\circ} \mathrm{C}$ respectively). Some $33 \%$ of Norwegians and $32 \%$ of Irish people smoke daily. Obesity rates are $9 \%$ in Norway and $10 \%$ in Ireland (obese defined as a body mass index $\geqslant 30$ ). Detailed, reliable data on diet are difficult to obtain, although it would seem that both countries have relatively high cholesterol diets. Emissions of harmful particulate matter are broadly comparable. Demographically, the two countries are similar. The proportions of the Norwegian and Irish populations $\geqslant 65$ years are $14.5 \%$ and $11.5 \%$ respectively. Some $6.9 \%$ of the population in both countries are young children ( $<4$ years). The bulk of the Norwegian and Irish populations are $20-55(49.9 \%$ and $47.5 \%$ respectively).

The mean (1986-1995) proportionate mortality rate of $46.2 \%$ for cardiovascular disease was identical in both countries (table 1). Respiratory disease accounted for a smaller share of total mortality in Norway than in Ireland $(9.9 \%$ and $13.8 \%)$. Crude mortality rates show that cardiovascular disease accounted for 4.1 deaths and 4.9 deaths per 1000 population and respiratory disease accounted for 1.3 deaths and 1.1 deaths per 1000 population in Ireland and Norway respectively. However, mean daily excess winter deaths from cardiovascular disease was 39.6 for Ireland and 6.3 for Norway. The corresponding

\footnotetext{
Department of

Environmental

Studies, University

College Dublin,

Richview, Dublin 14, Ireland

Correspondence to: Dr Clinch

(Peter.Clinch@ucd.ie)

Accepted for publication 10 May 2000
}

Table 1 Mean (1986-1995) rates of proportionate, crude, excess winter, and relative excess winter mortality from cardiovascular disease and respiratory disease, Ireland and Norway

\begin{tabular}{|c|c|c|c|c|}
\hline Mean mortality rates & Ireland & $95 \% C I$ & Norway & $95 \% C I$ \\
\hline Proportionate mortality from cardiovascular disease (\%) & 46.2 & $45.34,47.06$ & 46.2 & $45.26,47.14$ \\
\hline Proportionate mortality from respiratory disease $(\%)$ & 13.8 & $13.36,14.24$ & 9.9 & $9.36,10.44$ \\
\hline Crude mortality from cardiovascular disease per 1000 population & 4.1 & $3.94,4.26$ & 4.9 & $4.76,5.14$ \\
\hline Crude mortality from respiratory disease per 1000 population & 1.3 & $1.25,1.35$ & 1.1 & $1.03,1.17$ \\
\hline Excess winter deaths per day from cardiovascular disease & 39.6 & $32.59,46.61$ & 6.3 & $5.39,7.21$ \\
\hline Excess winter deaths per day from respiratory disease & 24.3 & $20.08,28.52$ & 4.3 & $3.32,5.28$ \\
\hline Relative excess winter mortality from cardiovascular disease & 0.25 & $0.21,0.29$ & 0.12 & $0.10,0.14$ \\
\hline Relative excess winter mortality from respiratory disease & 0.57 & $0.46,0.68$ & 0.4 & $0.32,0.48$ \\
\hline
\end{tabular}


figures for respiratory disease were 24.3 and 4.3. Relative excess winter mortality from cardiovascular disease was 0.25 in Ireland and 0.12 in Norway; the corresponding figures for respiratory disease were 0.57 and 0.4 .

\section{Discussion}

This study shows that, while Norway and Ireland exhibit similar (crude and proportionate) rates of mortality from cardiovascular and respiratory disease, relative excess winter mortality from cardiovascular disease in Ireland is 2.1 times that in Norway and for respiratory disease it is 1.4 times the Norwegian figure. A possible significant explanation for this strong seasonality in Ireland is that Irish housing standards are considerably poorer than those in Norway, allowing falls in outdoor temperature to have a much greater impact on internal temperatures. While Norwegian data control surprisingly well for the major risk factors for cardiovascular and respiratory diseases apart from housing standards, there are some factors that have not been controlled for, for example, environmental temperature is lower in Norway than in Ireland and clothing standards and health services may differ. Further research to test the hypothesis that there is a link between housing standards and excess winter mortality would be beneficial. Such research would help to establish whether improved energy efficiency in housing might be an effective preventative intervention to reduce excess winter mortality.

The authors are grateful to Professor William Keatinge (Queen Mary and Westfield College, London), Professor James Mercer (University of Tromsø), Dr Brenda Boardman (Oxford University), Dr Sheila MacEvilly and Dr Marie Lafoy (Eastern Health Board, Dublin), Dr James Clinch (Coombe Hospital, Dublin) and three anonymous referees. This paper is dedicated to the late Dr Zachary Johnson (Department of Health and Children, Dublin) without whom this study would not have been possible. Funding: financial assistance by Energy Action and the Government of Ireland Interim Council for the Humanities and Social Sciences is greatly appreciated.

Conflicts of interest: none.

1 The Eurowinter Group. Cold exposure and winter mortality from ischaemic heart disease, cerebrovascular disease, respiratory disease, and all causes in warm and cold regions of piratory disease, and all causes in war

2 Clinch JP, Healy JD. Alleviating fuel poverty in Ireland: A programme for the 21 st century. Int $\mathcal{f}$ Housing Science 999;23:203-15.

3 Smith GD, Hart C, Watt G, et al. Individual social class, area-based deprivation, cardiovascular disease risk factors and mortality: the Renfrew and Paisley study. $\mathcal{F}$ Epidemiol Community Health 1998;52:399-405.

4 Verhoeff AP, van Strien RT, Brunekreef B. Damp housing and childhood respiratory symptoms: the role of sensitization to dust mites and molds. Am $\mathcal{F}$ Epidemiol 1995;141: 103-10.

5 Laake K, Sverre JM. Winter excess mortality: a comparison between Norway and England plus Wales. Age Ageing 1996;25:343-8.

\section{Correction}

A printer's error occurred in this letter by Professors Porta and Alvarez-Dardet (2000;54:559-60). The correct title of the letter should have read "Authors' reply: How is causal inference [not interference] practised in the biological sciences?" 